\title{
Quality characteristics of glutinous rice-Makgeolli fermented with Korean yeast (SC Y204 and Y283) isolated from Nuruk
}

\author{
Sun Hee Kim, Ji-Young Mun, So Young Kim, Soo-Hwan Yeo* \\ Fermented and Processing Food Science Division, National Institute of Agricultural Science, RDA, Wanju 55365, Korea
}

\section{누룩에서 분리한 국산 효모 종균(SC Y204와 Y283)으로 빛은 찹쌀막걸리의 품질 특성}

\author{
김순희 · 문지영 · 김소영 · 여수환* \\ 농촌진흥청 국립농업과학원 발효가공식품과
}

\begin{abstract}
To investigate the effects of three different yeast starters (Fermivin, Y204, and Y283) in Nuruk prepared with Aspergillus luchuensis 74-5 on the quality of glutinous rice-Makgeolli (GRM), physicochemical properties and volatile flavor patterns were evaluated. GRM prepared under different fermentation conditions was analyzed for pH, total acidity, amino acidity, sugar, alcohol content, organic acids, and flavor patterns. Overall, the pH was very low, ranging from 3.11 to 3.82 . The acidity of GRM prepared with Y283 increased by $0.96 \%$ at $15{ }^{\circ} \mathrm{C}$ and, by $1.02-1.07 \%$ at $20{ }^{\circ} \mathrm{C}$ and showed the greatest increase of $1.11 \%$ at $25^{\circ} \mathrm{C}$, relative to the GRM prepared with control Fermivin and Y204. Moreover, Y283 resulted in a significantly increased alcohol content of $16 \%$ at $15{ }^{\circ} \mathrm{C}$ and $17.8 \%$ at $20^{\circ} \mathrm{C}$, which corresponded to a sharp decrease in sugar content $(p<0.05)$. Additionally, organic acid analysis revealed that the content of citric acid $(540.98 \mathrm{mg} / 100 \mathrm{~mL})$ and malic acid $(105.92 \mathrm{mg} / 100 \mathrm{~mL})$ in GRM prepared with Y283 was higher at $15^{\circ} \mathrm{C}$. The $92.71 \%$ contribution ratio of the first principal component identified by an electronic nose corresponded to different flavor patterns according to the fermentation temperature. Thus, different yeasts and temperatures affect the physiochemical and flavor characteristics of GRM, and Y283 may improve the quality of GRM.
\end{abstract}

Key words : yeast starter, glutinous rice, Nuruk, Makgeolli, volatile flavor

\section{서 론}

한국에서 가장 오래된 술, 막걸리는 전분질 원료와 누룩 및 물을 섞어 발효과정을 거쳐 생산된다(1). 다른 주류와 달리 단백질, 식이섬유, 당질, 비타민, 미량의 생리활성물질 등이 들어 있어 영양학적 가치가 높을 뿐 아니라 효모가 살아있어 약주, 과실주 및 증류주보다 특이한 맛을 가지고 있다(2). 농주라고도 불리는 막걸리는 유백색의 탁한 발효

*Corresponding author. E-mail : yeobio@korea.kr Phone : 82-63-238-3609, Fax : 82-63-238-3843

Received 7 October 2018; Revised 13 November 2018; Accepted 26 November 2018.

Copyright (C) The Korean Society of Food Preservation. All rights reserved.
액으로, 알코올은 6-18\%의 범위이며 대량생산 유통되는 시판 공장형은 6-7\%로 다른 술에 비해 알코올 도수가 낮아 서민들이 마시기에 좋은 술이다(3). 특히, 음주 후 두통이 거의 없으며 원료와 발효방법에 따라 텁텁하고 신맛과 향이 나는 가장 대중적이며 우리나라를 대표하는 술이라 할 수 있다(3). 국내 시판되는 전통주의 주원료는 멥쌀, 찹쌀, 밀가 루 등 지역에서 생산된 다양한 종류의 곡류를 사용한다(4). 최근, 사회적 환경변화인 핵가족, 간편식 패스트푸드의 시 장 점령, 이상기후 변화현상으로 2017년도 1인당 연간 쌀 소비량이 $61.8 \mathrm{~kg}$ 으로 매년 감소되는 실정에서 잉여 쌀의 소비활성 촉진방안으로 다양한 주종의 우리 술 개발이 요구 된다. 국내의 대부분 막걸리 업체는 멥쌀을 이용하여 생산 을 하고 있는 실정이지만 깔끔하고 감칠난 맛 등 막걸리의 품질 향상을 위하여 본 연구에서는 찹쌀을 주원료로 하였 
다. 찹쌀은 전분이 전체의 $70 \%$ 이상을 차지하고 그 중 amylopectin이 $95 \%$ 이상을 이루며(5), 지방질이 멥쌀보다 2 배 정도 높은 함량을 가지고 있어 발효 후 품질에 긍정적인 영향을 미친다(6). 찹쌀을 원료로 한 연구로는 찹쌀의 도정 도(7), 발효온도(8)에 따른 비교연구와 찹쌀과 멥쌀의 원료 에 따른 보고(9)등으로 찹쌀을 원료로 한 발효주의 연구가 더욱 요구되고 있다.

한편, 막걸리 제조 시 우수한 발효종균을 이용한 종국제 조의 기술은 막걸리 제품의 균일성과 맛의 다양성에 지대한 영향을 줄뿐만 아니라 이상 발효로 인한 감·산패 발생도 방지할 수 있어 중요하다. 따라서 막걸리의 품질 고급화 및 표준화를 위한 종균제조 기술은 우수한 발효특성을 가진 종균을 보다 안정적으로 유지 및 공급할 수 있어 수입산 종균과 경쟁을 할수가 있다. 본 연구진의 선행연구에서는 산 생성능이 우수한 토착종균 Aspergillus luchuensis 74-5(KACC 93235P)을 분리·동정하여 막걸리용 고체종국 의 안정적인 제품을 만드는데 기여하고 있다(10). 특히, 막 걸리의 주질 다양성의 또 다른 factor는 사용하는 효모 종류 에 따라 향미가 결정된다(11). 현재까지 막걸리 제조에 보고 된 효모는 주로 Saccharomyces, Pichia, Candida, Hansenular, Troulopsis 속 등이 알려져 있다(12). Saccharomyces cerevisiae는 가장 널리 사용되고 있는 효모 로서, 막걸리 이외에 주로 제과·제빵, 와인 및 맥주제조에 폭넓게 이용되고 있다. Jeon 등(13)에 따르면 막걸리 품질은 알코올, 총산, 향미로 결정되며 발효과정에서 생성되는 유 기산이 막걸리의 맛과 품질을 결정한다. 따라서 본 연구에 서는 토착 발효종균 A luchuensis 74-5(KACC 93235P)으로 발효제인 쌀누룩을 제조 후 전통 발효식품(누룩 등)에서 분리한 2종류의 S. cerevisiae Y204(KACC 93237P)와 $S$. cerevisiae Y283(KACC 93238P) 효모를 활용하여 제조한 찹쌀막걸리의 품질 특성을 조사하였다.

\section{재료 및 방법}

\section{실험재료, 균주 및 시약}

본 연구에 사용된 쌀은 2016년산 강화도에서 생산된 화 선찰쌀을 광천유통(Suwon, Korea)을 통하여 구입하였고, 발효제인 쌀누룩은 농촌진흥청 발효가공식품과에서 보관 한 산 생성능이 우수한 Aspergillus luchuensis 74-5(KACC 93235P) 종균을 Malto extract agar(Beton, Dickinson and company(BD), Sparks, MD, USA) 배지에 계대배양한 후, $4^{\circ} \mathrm{C}$ 에 보관하면서 사용하였다. 2 종류의 효모는 강원도 평 창군의 전통 발효식품들로부터 분리한 약산성에서 약알칼 리성 $\mathrm{pH}$ 범위뿐만 아니라 저온에서 중온 $\left(20-35^{\circ} \mathrm{C}\right)$ 까지 모 든 영역에서 생육이 우수한 균학적 특성을 가지며 알코올 생성능이 우수하고 풍미가 뛰어난 알코올 발효용 효모는
S. cerevisiae Y204 (KACC No. 93237P)와 Y283(KACC No. 93238P)를 사용하였고 대조구는 양조산업에 많이 사용되 는 수입산 $S$. cerevisiae Fermivin(Lallemand, Denmark)를 사용하였다(14). 그 외의 본 연구에 사용된 분석용 시약 (Sigma-Aldrich Co., Louis, MO, USA)은 특급을 사용하였 다.

\section{쌀누룩 제조}

A luchuensis 74-5 종균으로 빚은 백국은 쌀 $3 \mathrm{~kg}$ 을 수세 한 후, 1 시간의 침지와 50 분의 물 빼기 과정을 거쳐 1 시간 증자한 후, 품온이 $40^{\circ} \mathrm{C}$ 가 되도록 방냉하였다. 식은 고두밥 에 백국균(A luchuensis 74-5, $\mathrm{AL} 74-5)$ 을 $0.1 \%(\mathrm{w} / \mathrm{w})$ 접종하 여 제국기(Mini 15, Yaegaki Food Co., Hyogo, Japan)에 넣어 배양하였다. 약 20시간 후, 뒤집기를 수행하여 품온을 약 $38^{\circ} \mathrm{C}$ 로 유지하였으며 입상한 후, 약 5 시간 간격으로 뒤섞기 를 반복하여 품온의 과열을 방지하였으며, 배양 2 일 $(44 \mathrm{~h})$ 째 출국하여 $45^{\circ}$ C에서 1 일 건조(DS-80-3, Dasol Scientific Co., Ltd., Hwaseong, Korea)한 후, $4^{\circ} \mathrm{C}$ 에 저장하여 사용하였다.

\section{찹쌀막걸리 제조}

A luchuensis 74-5로 제조한 쌀누룩을 살균한 항아리에 넣고 3종류의 서로 다른 효모로 찹쌀막걸리를 제조하였다. 쌀누룩 $300 \mathrm{~g}$ 에 탕수한 담금수 $600 \mathrm{~mL}$ (가수량 200\%)를 넣고 S. cerevisiae Y204와 Y283 및 S. cerevisiae Fermivin 종균 $(0.01 \%)$ 으로 2 일간 발효시켜 밑술을 만들었다. 밑술의 술덧 전량에 고두밥 $300 \mathrm{~g}$ 과 탕수한 담금수 $600 \mathrm{~mL}$ 를 넣고 알코올 생성능이 우수한 2 종류의 국산 효모종균을 다양한 온도 $\left(15^{\circ} \mathrm{C}, 20^{\circ} \mathrm{C}, 25^{\circ} \mathrm{C}\right)$ 조건에서 발효기간에 따른 차이를 보기 위하여 8 일간 발효하였으며 2 일 간격으로 각각의 막 걸리 시료를 채취하여 품질 특성을 분석하였다.

\section{$\mathrm{pH}$, 적정산도 및 아미노산도 분석}

제조한 찹쌀막걸리의 $\mathrm{pH}$ 는 술덧 $30 \mathrm{~mL}$ 를 취하여 $\mathrm{pH}$ meter(Orion 3 star, Thremo scientific Co., MA, USA)로 측정 하였다. 적정산도 측정은 시료 $15 \mathrm{~mL}$ 를 취하여 여과지로 여과한 검체 $10 \mathrm{~mL}$ 를 $100 \mathrm{~mL}$ 삼각플라스크에 취한 다음, 0.5\% phenolphthalein(Sigma-Aldrich, San Fransisco, CA, USA) 지시약을 2-3 방울 떨어뜨리고 $0.1 \mathrm{~N} \mathrm{NaOH}$ 로 적정될 때까지 중화 적정하였으며 소비된 $\mathrm{NaOH}$ 양에 0.009 를 곱 하여 lactic acid의 양으로 환산하여 막걸리 시료 중의 총산 을 측정하였다(15). 아미노산도는 여과지로 여과한 검체 $10 \mathrm{~mL}$ 에 $0.5 \%$ phenolphthalein 지시약을 2-3방울 떨어뜨린 다음, $0.1 \mathrm{~N} \mathrm{NaOH}$ 로 적정한 다음, 중성포르말린 용액 5 $\mathrm{mL}$ 을 넣어 혼합하고 $0.1 \mathrm{~N} \mathrm{NaOH}$ 로 적정하여 담홍색이 될 때까지 소비된 $0.1 \mathrm{~N} \mathrm{NaOH}$ 의 $\mathrm{mL}$ 로 표시하였다(16).

\section{당도 측정}

당도 측정은 당도계(T400321 model, Atago Co., Tokyo, 
Japan)를 사용하였으며, 당도 측정용 시료는 찹쌀막걸리 술덧을 원심분리 $\left(8,000 \mathrm{rpm}, 15\right.$ 분, $4^{\circ} \mathrm{C}$, KUBOTA 6200 , Kubota Co., Ltd., Tokyo, Japan)한 상등액을 사용하였다.

\section{술덧의 알코올 함량 분석}

발효 술덧 내의 알코올 함량은 찹쌀막걸리 술덧을 부직 포로 조여과하여 얻어진 여액 $100 \mathrm{~mL}$ 에 증류수 $100 \mathrm{~mL}$ 를 넣어 혼합한 후 증류하였다. 증류액을 약 $80 \mathrm{~mL}$ 받은 다음 증류수를 넣어 $100 \mathrm{~mL}$ 로 정용하고 증류액의 온도를 $15^{\circ} \mathrm{C}$ 로 보정한 다음, 주정계를 이용하여 측정하였다(17).

\section{유기산 분석}

각각의 술덧 $10 \mathrm{~mL}$ 을 취하여 $0.2 \mu \mathrm{m}$ membrane filter (Millipore Co., Cork, Ireland)로 여과한 후, 유기산을 분석하 였으며 HPLC(LC-20A Prominence, Shimadzu Co., Kyoto, Japan)을 사용하고, 칼럼은 TSK gel ODS- $100 \mathrm{~V} 5 \mu$ $\mathrm{M}(4.6 \times 25 \mathrm{~cm}, \mathrm{TOSOH}$ Co., Nanyo, Japan), 이동상은 $8 \mathrm{mM}$ perchloric acid를 사용하였으며 유량은 $1.0 \mathrm{~mL} / \mathrm{min}$, 주입량 은 $10 \mu \mathrm{L}$, 측정은 $\mathrm{UV}(440 \mathrm{~nm})$ 를 사용하여 유기산을 분석하 였다.

\section{전자코에 의한 다중향기패턴 분석}

제조한 찹쌀막걸리의 다중 향기성분 분석은 $0.5 \mathrm{~mL}$ 을 $10 \mathrm{~mL}$ Vial(Ls-Phs-Psck GmbH, Langerwehe, Germany)에 넣고, $40^{\circ} \mathrm{C}$ 에서 30 분간 $500 \mathrm{rpm}$ 으로 교반하여 전자코(Fast GC based HRACLES flash Electronic nose. Alpha Mos, AMcombi PAL, Toulouse, France)를 이용하여 측정하였다. 시료분석에는 2개의 칼럼이 부착된 HRACLES E-nose(DB5 apolar and DB1701 Slightly polar)와 flame ionization detecter(FID)로 검출하였다. 주입량은 syringe type(5.0
$\mathrm{mL}-\mathrm{HS}$ )으로 칼럼 온도가 $25^{\circ} \mathrm{C}$ 로 유지된 상태에서 칼럼 헤드압력 $1.0 \mathrm{psi}$ 로 주입하였다. 분석 시 주입기의 온도는 $200^{\circ} \mathrm{C}$, detector $200^{\circ} \mathrm{C}$ 로 하고 주입기 압력은 $1.0 \mathrm{psi}$, 검출기 압력을 $39.0 \mathrm{psi}$ 로 하였다. 검출된 피크에 따라 차이를 0.900 이상과 RSD $20 \%$ 미만의 sensor를 선택하여 alpha Mos software를 이용하여 판별 분석법(Discriminant Function Analysis)과 SIMCA(Soft Independent Modelling of Class Analogy) method로 나타냈다. 시료분석 전 Kovats(Custom Alkanes Blend Standard)를 이용하여 탄소의 단쇄에서 장쇄 $\left(\mathrm{C}_{6}-\mathrm{C}_{16}\right)$ 까지의 피크 값을 얻어 Standard로 이용하였다.

\section{통계처리}

통계처리는 SAS(Statistical Analysis System, v7.1, SAS Institute, INC., Cary, NC, USA)에 의한 분산분석(ANOVA) 에 의해 검증하였으며, 유의성 비교는 Ducan's multiple range test로 $\mathrm{p}<0.05$ 수준에서 검증하였다.

\section{결과 및 고찰}

\section{발효기간과 온도에 따른 찹쌀막걸리의 $\mathrm{pH}$ 변화}

효모 종균별 발효온도와 발효기간에 따른 찹쌀막걸리의 술덧 $\mathrm{pH}$ 변화를 Table 1에 나타내었다. 본 연구에 사용된 S. cerevisiae $\mathrm{Y} 204$ 와 $\mathrm{Y} 283$ 은 대조구보다 $15^{\circ} \mathrm{C}$ 와 $20^{\circ} \mathrm{C}$ 에서 초기 담금 $\mathrm{pH}$ 3.23-3.72이었는데, 발효 2일째 $\mathrm{pH} 3.32-3.63$ 의 감소를 보이다가 6 일째에 증가하는 양상을 보였다. 초기 $\mathrm{pH}$ 감소는 술덧에 생육하는 미생물 작용의 탈아미노산에 의한 유기산 형성과 효모 증식으로 인한 인산 소비와 암모 니움 이온 흡수의 영향이고, 발효 6 일째 약간의 $\mathrm{pH}$ 의 증가 는 발효가 진행됨에 따라 생성된 유기산과 알코올이 서로

Table 1. Changes in $\mathrm{pH}$ of glutinous rice-Makgeolli according to different fermented starters during fermentation temperature and period

\begin{tabular}{|c|c|c|c|c|c|c|}
\hline \multirow{2}{*}{$\begin{array}{l}\mathrm{F}^{\mathrm{F}}{ }^{1)} \\
\left({ }^{\circ} \mathrm{C}\right)\end{array}$} & \multirow{2}{*}{ Samples ${ }^{2)}$} & \multicolumn{5}{|c|}{ Fermentation periods (day) } \\
\hline & & 0 & 2 & 4 & 6 & 8 \\
\hline \multirow{3}{*}{15} & Control & $3.61 \pm 0.12^{\mathrm{b} 33)}$ & $3.82 \pm 0.07^{\mathrm{a}}$ & $3.28 \pm 0.12^{\mathrm{c}}$ & $3.37 \pm 0.13^{\mathrm{c}}$ & $3.28 \pm 0.06^{\mathrm{C}}$ \\
\hline & Y204 & $3.55 \pm 0.06^{\mathrm{a}}$ & $3.45 \pm 0.23^{\mathrm{a}}$ & $3.35 \pm 0.04^{\mathrm{a}}$ & $3.35 \pm 0.06^{\mathrm{a}}$ & $3.42 \pm 0.07^{\mathrm{a}}$ \\
\hline & Y283 & $3.72 \pm 0.10^{\mathrm{a}}$ & $3.63 \pm 0.29^{\mathrm{a}}$ & $3.51 \pm 0.14^{\mathrm{a}}$ & $3.72 \pm 0.04^{\mathrm{a}}$ & $3.62 \pm 0.06^{\mathrm{a}}$ \\
\hline \multirow{3}{*}{20} & Control & $3.41 \pm 0.13^{\mathrm{a}}$ & $3.39 \pm 0.24^{\mathrm{a}}$ & $3.27 \pm 0.04^{\mathrm{a}}$ & $3.35 \pm 0.25^{\mathrm{a}}$ & $3.54 \pm 0.06^{\mathrm{a}}$ \\
\hline & Y204 & $3.23 \pm 0.12^{c}$ & $3.32 \pm 0.13^{b c}$ & $3.22 \pm 0.06^{\mathrm{c}}$ & $3.46 \pm 0.10^{\mathrm{ab}}$ & $3.53 \pm 0.10^{\mathrm{a}}$ \\
\hline & Y283 & $3.71 \pm 0.10^{\mathrm{a}}$ & $3.54 \pm 0.06^{\mathrm{ab}}$ & $3.09 \pm 0.08^{\mathrm{d}}$ & $3.35 \pm 0.11^{\mathrm{c}}$ & $3.41 \pm 0.14^{\mathrm{bc}}$ \\
\hline \multirow{3}{*}{25} & Control & $3.11 \pm 0.02^{\mathrm{c}}$ & $3.34 \pm 0.22^{b}$ & $3.47 \pm 0.10^{\mathrm{ab}}$ & $3.70 \pm 0.04^{\mathrm{a}}$ & $3.67 \pm 0.14^{\mathrm{a}}$ \\
\hline & Y204 & $3.17 \pm 0.06^{b}$ & $3.49 \pm 0.06^{\mathrm{a}}$ & $3.46 \pm 0.16^{\mathrm{a}}$ & $3.61 \pm 0.04^{\mathrm{a}}$ & $3.59 \pm 0.04^{\mathrm{a}}$ \\
\hline & Y283 & $3.65 \pm 0.09^{\mathrm{a}}$ & $3.35 \pm 0.08^{b}$ & $3.36 \pm 0.17^{\mathrm{b}}$ & $3.53 \pm 0.11^{\mathrm{ab}}$ & $3.57 \pm 0.06^{\mathrm{a}}$ \\
\hline
\end{tabular}

${ }^{1)}$ F.T, fermentation temperature

${ }^{2}$ Control, S. cerevisiae Fermivin; Y204, S. cerevisiae Y204(KACC 93237P); Y283, S. cerevisiae Y283(KACC 93238P).

${ }^{3}$ Means with different letters in the same column are significantly different $(\mathrm{p}<0.05)$ by Duncan's multiple range test. All values are triplicate determination. Results are shown as mean $\pm \mathrm{SD}$. 
반응하여 ester와 같은 향미 형성 등에 이용된 것으로 보인 다(18). 그러나 $25^{\circ} \mathrm{C}$ 에서는 각각의 효모 종균으로 빚은 찹쌀 막걸리 술덧의 $\mathrm{pH}$ 는 담금 직후에 가장 낮은 $\mathrm{pH}$ 3.11-3.65를 나타내다가 발효기간이 길어지면서 약간씩 증가하는 추세 를 보였다(p<0.05). 이는 높은 발효온도에서 유기산을 생성 하는 젖산균의 번식이 왕성해지고 활성이 강해 $\mathrm{pH}$ 가 낮다 (19)가 시간이 지나면서 효모가 많은 알코올을 생성하는 동시에 불포화지방산 및 sterols를 많이 생성하기 때문이라 고 생각된다(20). 이러한 결과는 Jin 등(21)이 진양주의 발효 온도에 따른 품질 평가에서도 보고한 바 있다. 발효 기간에 따른 $\mathrm{pH}$ 변화는 당화효소 또는 단백질 분해 효소의 작용으 로, 원료미의 맛 성분 용출 등으로 막걸리 주질과 맛, 물리적 및 미생물학적 안정성에 영향을 준다. 이는 효모의 성장과
전분질의 완충 능력을 자극하기 때문에 발효 및 알코올 변화의 지표로 이용되기도 한다. 본 연구에서 온도와 발효 기간에 따른 찹쌀막걸리의 술덧 $\mathrm{pH}$ 변화는 전반적으로 3.11-3.82로 매우 낮은 수준을 나타내므로 적정산도나 알코 올 함량의 증가를 예측할 수 있었다.

발효기간과 온도에 따른 찹쌀막걸리의 산도 및 아미노산 도 변화

효모 종균별 발효온도와 발효기간에 따른 찹쌀막걸리 술덧의 적정산도 변화를 Fig. $1 \mathrm{~A}$ 에 나타내고 있다. 담금 직후, 산도는 발효온도별 $\left(15^{\circ} \mathrm{C}, 20^{\circ} \mathrm{C}, 25^{\circ} \mathrm{C}\right)$ 각각 $0.5-0.6 \%$, $0.5-0.8 \%, 0.6-0.9 \%$ 나타냈다. 2종류의 효모 Y204와 Y283은 각각의 온도에서 발효 2 일째부터 산도의 증가를 보였다.
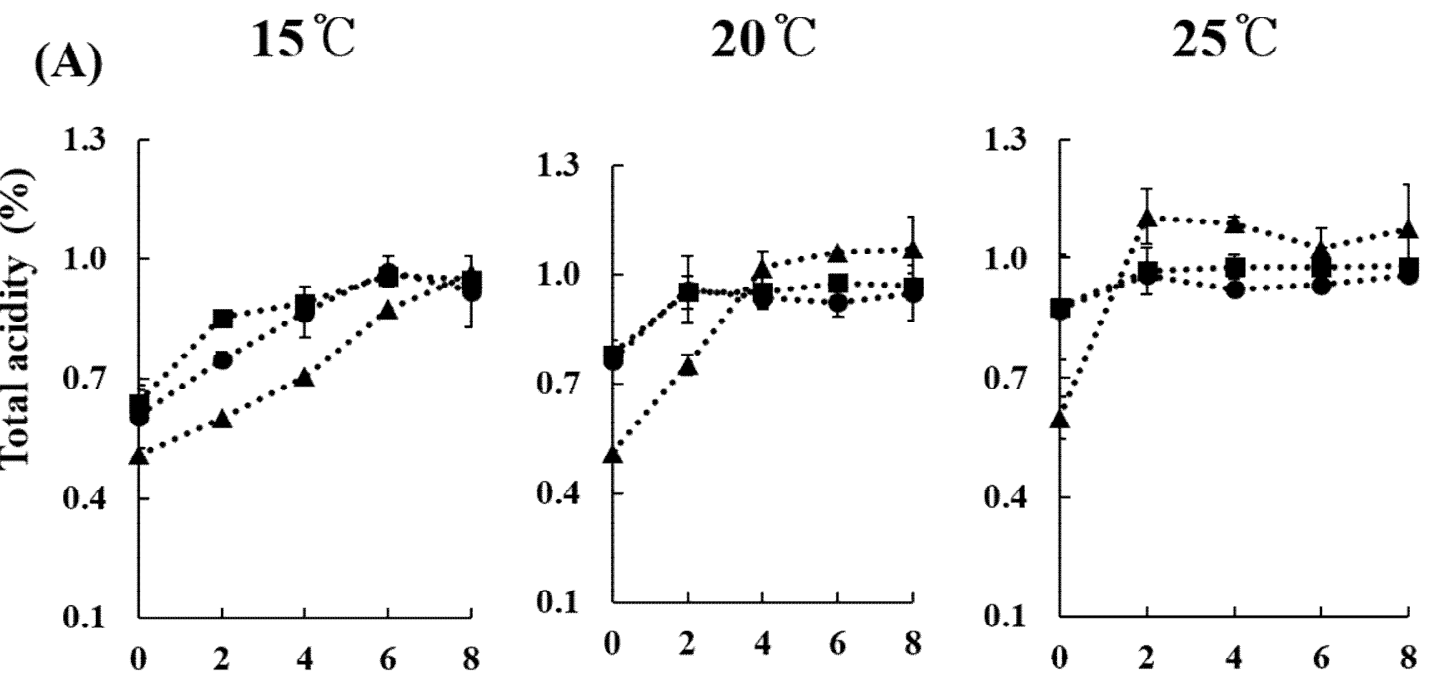

(B)
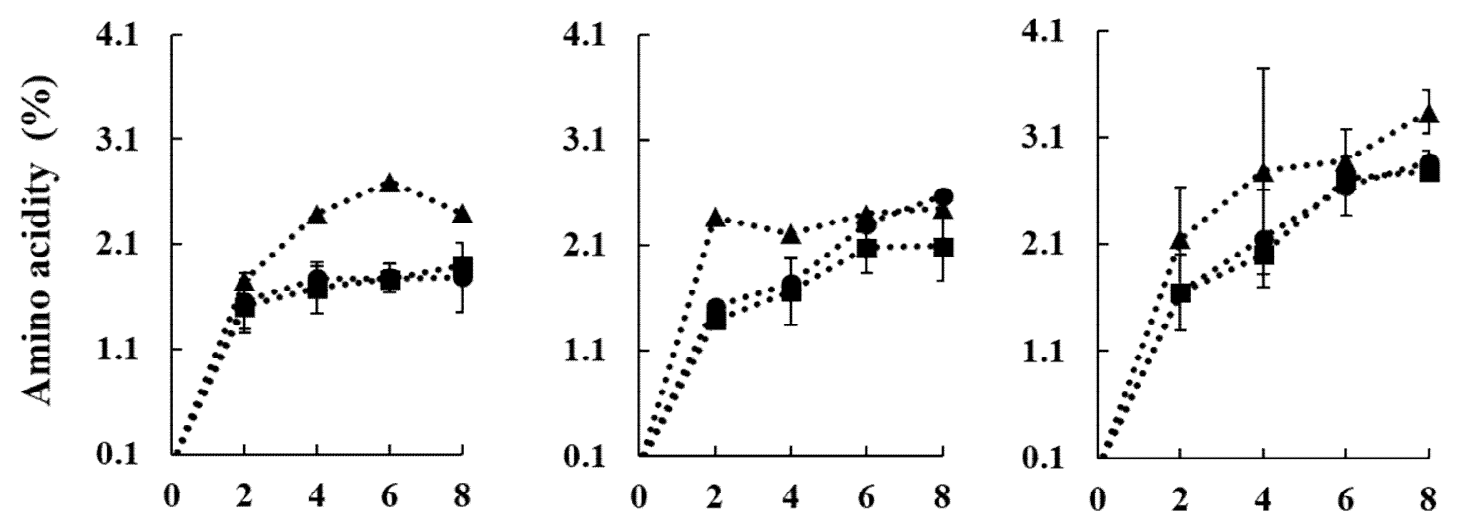

\section{Fermentation periods (days)}

Fig. 1. Changes in total acidity and amino acidity of glutinous rice-Makgeolli according to different fermented starters during fermentation temperature $\left(15^{\circ} \mathrm{C}, 20^{\circ} \mathrm{C}\right.$, and $\left.25^{\circ} \mathrm{C}\right)$ and period.

Data are presented as the mean for 3 independent experiments. Error bars indicate $\mathrm{SD}(\mathrm{p}<0.05)$.

- $S$. cerevisiae Fermivin; $\mathbf{\square}$ S. cerevisiae Y204; $\mathbf{\Delta}$ S. cerevisiae Y283. 
효모 $\mathrm{Y} 283$ 의 산도는 $15^{\circ} \mathrm{C}$ 에서 8 일째 $0.96 \%$ 로, $20^{\circ} \mathrm{C}$ 에서는 4일째 $1.02 \%$ 로 증가하면서 8 일째 $1.07 \%$ 로 증가하였고, 2 $5{ }^{\circ} \mathrm{C}$ 에서는 2 일째 $1.11 \%$ 로 최고의 증가를 보였다. 이는 Table 1 에 나타낸 것처럼 찹쌀막걸리 발효시 $\mathrm{pH}$ 가 감소하 는 시점에 산도가 증가하는 상관관계를 나타내고 있다. 한 편, 대조구로 사용한 수입산 효모(Fermivin)와 Y204의 산도 는 $20^{\circ} \mathrm{C}$ 와 $25^{\circ} \mathrm{C}$ 의 발효 2 일째 $0.95-0.96 \%$ 의 증가 추세로 약간의 변화와 함께 8 일째까지 산도를 유지하였다. $15^{\circ} \mathrm{C}$ 에 서 대조구인 Fermivin 효모와 Y204의 산도는 발효기간에 따라 서서히 증가해 6일째 $0.97 \%$ 로 최고 산도를 나타냈지 만 8 일째는 $0.92 \%$ 로 감소하였다. 이러한 결과는 Kang 등 (22)의 연구에서 막걸리의 발효에 따른 총산을 측정한 결과,
발효온도와 발효기간에 따라 점차적으로 증가한 결과와 유사하였다. 본 연구에서 찹쌀막걸리 담금 직후의 산도 변 화는 산 생성능이 우수한 토착 종균 $A$ luchuensis 74-5(KACC 93235P)로 제조한 쌀누룩의 영향으로 여겨진 다. 술덧의 알코올 발효가 진행되면서 젓산이나 효모 발효 로 생성되는 유기산의 영향으로도 총산 양이 증가되며 생성 된 유기산이 알코올 등과 결합하여 향미 성분을 만들고 발효 후기에는 향미성분들이 감소되어진다. 특히, 생성된 산도는 발효주 제조 시 발효과정을 모니터링 할 수 있는 가장 중요한 지표이며, 효모 Y283이 Y204와 대조구 (Fermivin)보다 발효 효과가 유의적으로 크게 나타남을 알 수 있었다 $(\mathrm{p}<0.05)$.
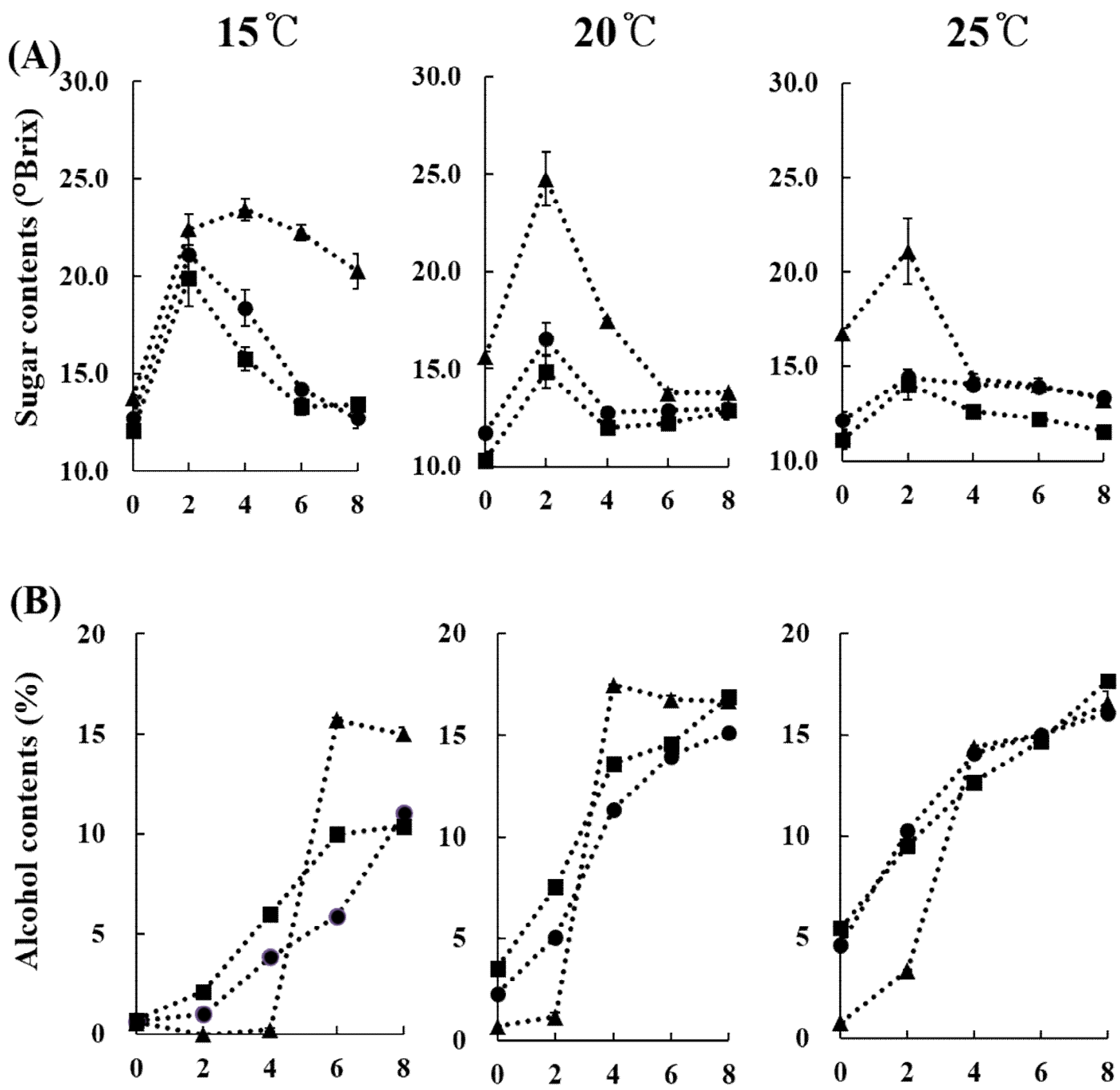

Fermentation periods (days)

Fig. 2. Changes in sugar and alcohol contents of glutinous rice-Makgeolli according to different fermented starters during fermentation temperature $\left(15^{\circ} \mathrm{C}, 20^{\circ} \mathrm{C}\right.$, and $\left.25^{\circ} \mathrm{C}\right)$ and period.

Data are presented as the mean for 3 independent experiments. Error bars indicate $\mathrm{SD}(\mathrm{p}<0.05)$.

- S. cerevisiae Fermivin; $\mathbf{n}$, S. cerevisiae Y204; $\boldsymbol{\Delta}$, S. cerevisiae Y283. 
Fig. 1B의 아미노산도는 원료에 포함된 단백질이 acidic protease와 기타 peptidase 등의 분해효소 작용에 의해 유리 되는 아미노산을 측정한 수치로서, 분해된 아미노산은 배 양 중 효모의 영양원으로 이용되어 고급 알코올 및 에스테 르 등의 향기성분으로 분해되기 때문에 적당량의 유리 아미 노산은 주류에 다양한 맛을 부여하여 기호도에 긍정적인 영향을 준다. 종균별 제조한 찹쌀막걸리의 아미노산도는 온도와 발효시간이 증가함에 따라 대조구로 사용한 시판 효모인 Fermivin과 토착 효모 Y204와 Y283은 각각 1.53$2.87 \%, 1.39-2.78 \%, 1.76-3.33 \%$ 로 증가하는 경향을 보였다. 전반적으로 발효초기인 2일째 급격히 증가하였고 사용한 종균에 따라 증가 패턴의 변화를 보였다. 특히, 효모 Y283에 의한 아미노산도 증가가 유의적 차이를 나타내었다 $(\mathrm{p}<0.05)$. 발효온도 $25^{\circ} \mathrm{C}$ 를 제외하고는 발효 종료일까지 증 가함이 완만하게 유지되는 것은 Lee 등(23)이 보고한 결과 와 비슷하다. 아미노산도가 $3.0 \%$ 이하가 되면 발효주에서 느끼한 맛은 없을 것으로 보고하고 있다(24).

\section{발효기간과 온도에 따른 찹쌀막걸리의 당도와 알코올 함 량 변화}

효모 종균별 발효온도와 기간에 따른 찹쌀막걸리 술덧의 당도 변화를 Fig. 2A에 나타내었다. 찹쌀막걸리 담금 초기 당도 함량은 발효온도 $\left(15^{\circ} \mathrm{C}, 20^{\circ} \mathrm{C}, 25^{\circ} \mathrm{C}\right)$ 에 따라 12.07-13.77 ${ }^{\circ} \mathrm{Brix}, 10.33-15.63{ }^{\circ} \mathrm{Brix}, 11.10-16.73{ }^{\circ} \mathrm{Brix}$ 로 나타났다. 3종 류의 발효온도에서 대조구로 사용한 효모 Fermivin과 토착 효모 Y204, Y283은 발효 2일째 14.43-21.10 ${ }^{\circ} \mathrm{Brix}$, 14.07-19.93 ${ }^{\circ} \mathrm{Brix}, 21.10-24.77{ }^{\circ} \mathrm{Brix}$ 로 최고의 당도 함량을 나타냈다. 이후 알코올이 생성되면서 당 함량은 감소하기 시작하여 발효가 종료되는 8 일에는 $12.73-20.27{ }^{\circ} \mathrm{Brix}$, 12.87-13.80 ${ }^{\circ} \mathrm{Brix}, 11.60-13.40{ }^{\circ} \mathrm{Brix}$ 로 각각 나타났다. 알코 올 발효 2일째, Y283 효모종균은 대조구인 수입산 효모 (Fermivin)와 Y204 효모에 비해 당도가 높았으며 이들 간의 유의적 차이를 나타냈다 $(\mathrm{p}<0.05)$. 종균별 제조한 찹쌀막걸 리는 발효 2 일까지 당도 함량이 계속 증가하다가 그 이후부 터는 술덧의 전분질이 당화 amylase 작용으로 당분으로 분해됨과 동시에 효모의 영양원이나 발효 기질로 이용될 뿐만 아니라 발효 후기에는 당도 함량이 감소되는 것으로 생각된다(25). 한편 Yang과 $\operatorname{Eun(24)ㅇㅡㄴ~ㅊㅗㅇㄷㅏㅇ~ㅎㅏㅁㄹㅑㅇㅇㅣ~ㄱㅡㅂㄱㅕㄱㅎㅏ~}$ 게 감소할 때 술덧의 알코올 함량이 가장 급속하게 증가하 는 시기라고 보고하였다.

효모 종균별 발효온도와 기간에 따른 찹쌀막걸리의 알코 올 함량 변화는 Fig. 2B에 나타내었다. 효모 종균별 찹쌀막 걸리의 담금 초기 알코올 함량은 발효온도 $\left(15^{\circ} \mathrm{C}, 20^{\circ} \mathrm{C}, 2\right.$ $5{ }^{\circ} \mathrm{C}$ )에 따라서 $0.6-0.7 \%, 0.7-3.8 \%, 0.8-5.4 \%$ 로 나타났다. 효모 $\mathrm{Y} 283$ 은 발효 $15^{\circ} \mathrm{C}$ 에서 발효 6 일째, $20^{\circ} \mathrm{C}$ 는 4 일째, $25^{\circ} \mathrm{C}$ 에서는 발효 8 일째, 각각 $16 \%, 17.50 \%, 16.53 \%$ 로 최고의 유의적인 알코올 생산능을 보였다 $(\mathrm{p}<0.05)$. 대조구인 수입
산 시판 효모인 Fermivin과 Y204 효모는 발효 2일째부터 서서히 알코올 함량이 증가하여 각 발효온도 $\left(15^{\circ} \mathrm{C}, 20^{\circ} \mathrm{C}\right.$, $25^{\circ} \mathrm{C}$ )의 발효 종료시점인 8 일 차의 알코올 함량이 Fig. $2 \mathrm{~B}$ 에 각각 $10.40-11.07 \%, 15.13-16.90 \%, 16.03-17.67 \%$ 로 최대치 를 보였다. Fig. 2에 나타난 찹쌀막걸리 술덧의 당도 감소와 알코올 함량 증가 결과는 Yang과 $\operatorname{Eun(26)}$ 이 보고한 것처럼 서로 상관관계를 보여 주고 있다. 한편 효모 Y283으로 담근 막걸리의 알코올 함량이 최고치 $15 \%$ 이상을 나타낼 때, 당도 함량이 최고치에서 감소하기는 했지만 $20{ }^{\circ} \mathrm{Brix}$ 이상 의 함량을 나타내고 있다. 이는 효모 Y283이 Y204나 Fermivin에 비해 발효 후 단당류인 glucose와 fructose 및 이당류인 maltose 등의 잔당이 많이 남아 있는 것으로 여겨 진다. Jang 등(27)과 $\mathrm{Kim}$ 등(28)의 보고에 의하면 주류에 사용되는 효모는 발효온도가 높아질수록 알코올 생산 속도 가 빨라진다고 보고한 바 있다. 본 연구에서도 3 종류의 효모 로 찹쌀막걸리를 제조하였을 때, $20^{\circ} \mathrm{C}$ 와 $25^{\circ} \mathrm{C}$ 의 발효조에서 생산된 알코올 함량이 $15^{\circ} \mathrm{C}$ 보다 높게 나타났다. 그러나 이 들 효모 종균 중에서 $\mathrm{Y} 283$ 은 $20^{\circ} \mathrm{C}$ 와 $25^{\circ} \mathrm{C}$ 보다 낮은 온도 $(1$ $5{ }^{\circ} \mathrm{C}$ )조건에서 알코올 발효가 잘 되는 것을 알 수 있다(Fig. 2). $15^{\circ} \mathrm{C}$ 저온에서 발효 6 일째 $16.5 \%$ 의 알코올을 만든 후, 발효 8일부터 감소하기 시작한 것으로 보아 Y283은 다른 효모보다 저온발효조건에서 알코올 생성능이 우수한 종균 으로 여겨진다. 따라서 수입산 효모를 대체하기 위해서라 도 Y283 효모는 막걸리뿐만 아니라 약주 제조에도 충분히 사용할 수 있을 것으로 여겨진다. 서로 다른 효모종균별로 빚은 찹쌀막걸리는 $\mathrm{Kim}$ 등(29)이 누룩에서 분리한 효모로 빚은 찹쌀 발효주보다 더 다양한 온도 스펙트럼에서 발효기 간이 2 배 단축되었고 알코올 발효능도 더 우수한 차이를 보임으로써 침체된 막걸리산업의 활성화에 기여 할 수 있다 고 여겨진다.

\section{찹쌀막걸리의 유기산 변화}

효모 종균별 제조한 찹쌀막걸리의 유기산 분석 결과를 Table 2에 나타내었다. 발효과정에서 생성되는 유기산은 막걸리의 맛과 품질을 결정하는데 중요한 역할을 한다 $(30,31)$. 유기산은 술에서 산미를 내는 중요한 지표성분으 로 막걸리의 맛을 높이는 역할도 하지만 acetic acid가 다량 존재하면 발효과정에서 알코올 산화로 초산발효단계로 진 행되므로 주질을 저하시키는 요인이 되기도 한다(32). 막걸 리 제조 시 생성되는 대부분의 유기산은 lactic acid, acetic acid, succinic acid 및 citric acid 등의 결과가 보고되었다 (33). Table 2에 나타낸 것처럼 S. cerevisiae Y283을 비롯한 Y204와 대조구인 시판 효모(Fermivin)는 전반적으로 citric acid 함량이 가장 높았고, malic acid, lactic acid 순으로 나타 난 것이 열처리하지 않은 막걸리의 품질특성(34)과 비슷하 였다. 유기산 중 acetic acid, succinic acid, fumaric acid 및 propionic acid는 발효 초기 미량으로 감지되다가 발효온도 
Table 2. Concentration of organic acids in glutinous rice-Makgeolli by different fermented starters according to the fermentation temperature and period

\begin{tabular}{|c|c|c|c|c|c|c|c|}
\hline \multirow{2}{*}{ Organic acid } & \multirow{2}{*}{$\begin{array}{l}\text { F.T } \\
\left({ }^{1)}\right)\end{array}$} & \multirow{2}{*}{ Starters $^{2)}$} & \multicolumn{5}{|c|}{ Fermentation period (day, $\mathrm{mg} / 100 \mathrm{~mL}$ ) } \\
\hline & & & 0 & 2 & 4 & 6 & 8 \\
\hline \multirow{9}{*}{ Malic acid } & \multirow{3}{*}{15} & Control & $24.17 \pm 1.01^{\mathrm{d} 3)}$ & $52.88 \pm 0.13^{\mathrm{b}}$ & $89.49 \pm 0.53^{\mathrm{a}}$ & $32.79 \pm 0.88^{\mathrm{c}}$ & $22.22 \pm 0.89^{\mathrm{e}}$ \\
\hline & & Y204 & $16.98 \pm 0.38^{\mathrm{e}}$ & $79.81 \pm 0.80^{\mathrm{a}}$ & $40.65 \pm 0.88^{b}$ & $27.89 \pm 1.04^{\mathrm{c}}$ & $18.58 \pm 0.65^{\mathrm{d}}$ \\
\hline & & Y283 & $15.37 \pm 0.43^{\mathrm{e}}$ & $105.92 \pm 0.92^{\mathrm{a}}$ & $21.78 \pm 1.29^{\mathrm{d}}$ & $75.31 \pm 0.66^{b}$ & $31.05 \pm 0.47^{\mathrm{c}}$ \\
\hline & \multirow{3}{*}{20} & Control & $35.04 \pm 0.18^{\mathrm{c}}$ & $45.66 \pm 0.52^{\mathrm{a}}$ & $37.37 \pm 0.58^{b}$ & $25.85 \pm 0.95^{\mathrm{d}}$ & $17.86 \pm 0.82^{\mathrm{e}}$ \\
\hline & & Y204 & $20.89 \pm 0.23^{b}$ & $38.26 \pm 0.66^{\mathrm{a}}$ & $38.37 \pm 0.78^{\mathrm{a}}$ & $21.82 \pm 0.56^{\mathrm{b}}$ & $7.47 \pm 0.71^{\mathrm{c}}$ \\
\hline & & Y283 & $27.58 \pm 0.61^{\mathrm{d}}$ & $53.89 \pm 0.92^{\mathrm{a}}$ & $47.02 \pm 0.93^{b}$ & $32.95 \pm 0.33^{c}$ & $21.82 \pm 1.21^{\mathrm{e}}$ \\
\hline & \multirow{3}{*}{25} & Control & $23.11 \pm 0.86^{b}$ & $35.96 \pm 0.24^{\mathrm{a}}$ & $20.77 \pm 0.81^{c}$ & $13.63 \pm 0.65^{\mathrm{d}}$ & $11.30 \pm 1.00^{\mathrm{e}}$ \\
\hline & & Y204 & $20.77 \pm 0.78^{b}$ & $35.27 \pm 0.34^{\mathrm{d}}$ & $9.50 \pm 0.56^{\mathrm{e}}$ & $17.96 \pm 0.95^{\mathrm{c}}$ & $12.17 \pm 0.95^{\mathrm{e}}$ \\
\hline & & Y283 & $11.36 \pm 0.01^{\mathrm{d}}$ & $67.23 \pm 0.50^{\mathrm{a}}$ & $32.17 \pm 0.78^{b}$ & $20.12 \pm 0.31^{\mathrm{c}}$ & $11.65 \pm 0.87^{\mathrm{d}}$ \\
\hline \multirow{9}{*}{ Lactic acid } & \multirow{3}{*}{15} & Control & $11.71 \pm 0.84^{\mathrm{e}}$ & $28.91 \pm 0.91^{\mathrm{c}}$ & $19.13 \pm 1.08^{\mathrm{d}}$ & $42.01 \pm 0.92^{\mathrm{b}}$ & $44.07 \pm 0.94^{\mathrm{a}}$ \\
\hline & & Y204 & $11.47 \pm 0.59^{\mathrm{e}}$ & $59.62 \pm 0.62^{\mathrm{d}}$ & $74.17 \pm 0.93^{\mathrm{c}}$ & $91.45 \pm 1.28^{\mathrm{a}}$ & $82.55 \pm 0.41^{b}$ \\
\hline & & Y283 & $38.61 \pm 0.59^{\mathrm{a}}$ & $\mathrm{ND}^{4)}$ & $4.62 \pm 0.76^{\mathrm{d}}$ & $30.13 \pm 1.02^{\mathrm{b}}$ & $15.83 \pm 0.62^{c}$ \\
\hline & \multirow{3}{*}{20} & Control & $23.40 \pm 0.61^{\mathrm{d}}$ & $43.51 \pm 1.01^{\mathrm{c}}$ & $68.43 \pm 0.60^{\mathrm{a}}$ & $58.87 \pm 0.87^{\mathrm{b}}$ & $42.25 \pm 0.78^{c}$ \\
\hline & & Y204 & $12.27 \pm 0.73^{\mathrm{e}}$ & $74.11 \pm 0.85^{\mathrm{c}}$ & $94.73 \pm 0.69^{\mathrm{a}}$ & $75.51 \pm 0.51^{\mathrm{b}}$ & $31.63 \pm 0.74^{\mathrm{d}}$ \\
\hline & & Y283 & $19.92 \pm 0.94^{c}$ & $\mathrm{ND}$ & $49.74 \pm 0.97^{b}$ & $85.23 \pm 0.78^{\mathrm{a}}$ & $84.71 \pm 0.26^{\mathrm{a}}$ \\
\hline & \multirow{3}{*}{25} & Control & $16.10 \pm 0.86^{\mathrm{e}}$ & $47.82 \pm 0.74^{\mathrm{a}}$ & $37.17 \pm 0.29^{b}$ & $34.95 \pm 0.69^{c}$ & $33.22 \pm 0.51^{\mathrm{d}}$ \\
\hline & & Y204 & $24.53 \pm 0.78^{\mathrm{e}}$ & $78.82 \pm 0.85^{b}$ & $36.01 \pm 0.44^{\mathrm{d}}$ & $88.13 \pm 1.02^{\mathrm{a}}$ & $67.32 \pm 0.37^{c}$ \\
\hline & & Y283 & $7.11 \pm 0.30^{\mathrm{e}}$ & $55.99 \pm 1.05^{\mathrm{d}}$ & $87.67 \pm 0.95^{b}$ & $94.57 \pm 0.47^{\mathrm{a}}$ & $84.84 \pm 0.95^{\mathrm{c}}$ \\
\hline \multirow{9}{*}{ Acetic acid } & \multirow{3}{*}{15} & Control & $12.23 \pm 0.78^{b}$ & $12.69 \pm 0.48^{b}$ & $25.21 \pm 0.45^{\mathrm{a}}$ & $\mathrm{ND}$ & $\mathrm{ND}$ \\
\hline & & Y204 & $18.04 \pm 0.34^{\mathrm{a}}$ & $\mathrm{ND}$ & ND & $\mathrm{ND}$ & $\mathrm{ND}$ \\
\hline & & Y283 & $15.15 \pm 0.21^{\mathrm{c}}$ & $63.10 \pm 0.91^{\mathrm{a}}$ & $7.01 \pm 0.22^{\mathrm{d}}$ & $34.79 \pm 1.00^{\mathrm{b}}$ & $5.61 \pm 0.37^{\mathrm{d}}$ \\
\hline & \multirow{3}{*}{20} & Control & $5.49 \pm 0.10^{\mathrm{a}}$ & $\mathrm{ND}$ & $\mathrm{ND}$ & $\mathrm{ND}$ & $\mathrm{ND}$ \\
\hline & & Y204 & $1.45 \pm 0.22^{\mathrm{a}}$ & $\mathrm{ND}$ & $\mathrm{ND}$ & $\mathrm{ND}$ & $\mathrm{ND}$ \\
\hline & & Y283 & $20.09 \pm 1.00^{\mathrm{a}}$ & $\mathrm{ND}$ & $\mathrm{ND}$ & $\mathrm{ND}$ & $\mathrm{ND}$ \\
\hline & \multirow{3}{*}{25} & Control & $\mathrm{ND}$ & $\mathrm{ND}$ & $\mathrm{ND}$ & $\mathrm{ND}$ & $\mathrm{ND}$ \\
\hline & & Y204 & $\mathrm{ND}$ & $\mathrm{ND}$ & $\mathrm{ND}$ & $\mathrm{ND}$ & $\mathrm{ND}$ \\
\hline & & Y283 & $5.46 \pm 0.42^{\mathrm{a}}$ & $\mathrm{ND}$ & $\mathrm{ND}$ & $\mathrm{ND}$ & $\mathrm{ND}$ \\
\hline \multirow{9}{*}{ Citric acid } & \multirow{3}{*}{15} & Control & $203.47 \pm 1.10^{\mathrm{e}}$ & $259.47 \pm 0.80^{d}$ & $391.57 \pm 0.69^{\mathrm{a}}$ & $289.09 \pm 0.96^{b}$ & $268.55 \pm 0.50^{c}$ \\
\hline & & Y204 & $228.12 \pm 0.77^{\mathrm{e}}$ & $412.23 \pm 0.34^{\mathrm{a}}$ & $387.25 \pm 0.01^{b}$ & $349.95 \pm 1.02^{\mathrm{c}}$ & $321.35 \pm 1.29^{d}$ \\
\hline & & Y283 & $210.65 \pm 0.94^{\mathrm{e}}$ & $540.98 \pm 1.06^{\mathrm{a}}$ & $416.59 \pm 0.56^{c}$ & $483.06 \pm 0.07^{b}$ & $299.56 \pm 0.58^{\mathrm{d}}$ \\
\hline & \multirow{3}{*}{20} & Control & $208.43 \pm 0.51^{\mathrm{e}}$ & $382.55 \pm 0.75^{\mathrm{a}}$ & $365.80 \pm 0.85^{b}$ & $231.74 \pm 0.81^{\mathrm{d}}$ & $239.35 \pm 0.88^{\mathrm{c}}$ \\
\hline & & Y204 & $223.61 \pm 0.90^{d}$ & $374.65 \pm 0.60^{\mathrm{a}}$ & $257.89 \pm 1.00^{c}$ & $272.46 \pm 0.90^{b}$ & $145.63 \pm 0.75^{e}$ \\
\hline & & Y283 & $254.49 \pm 0.45^{\mathrm{e}}$ & $458.86 \pm 0.07^{\mathrm{a}}$ & $331.81 \pm 1.40^{c}$ & $345.97 \pm 0.74^{b}$ & $314.05 \pm 0.98^{\mathrm{d}}$ \\
\hline & \multirow{3}{*}{25} & Control & $222.42 \pm 0.65^{\mathrm{d}}$ & $359.41 \pm 1.43^{\mathrm{a}}$ & $276.12 \pm 0.94^{\mathrm{b}}$ & $215.96 \pm 0.56^{\mathrm{e}}$ & $252.44 \pm 0.69^{c}$ \\
\hline & & Y204 & $225.22 \pm 0.33^{c}$ & $359.69 \pm 0.71^{\mathrm{a}}$ & $164.36 \pm 0.81^{\mathrm{e}}$ & $213.59 \pm 0.60^{d}$ & $232.44 \pm 0.84^{b}$ \\
\hline & & Y283 & $226.90 \pm 0.99^{\mathrm{e}}$ & $438.43 \pm 0.69^{\mathrm{a}}$ & $323.58 \pm 0.58^{\mathrm{b}}$ & $321.02 \pm 0.50^{c}$ & $276.27 \pm 0.74^{\mathrm{d}}$ \\
\hline \multirow{9}{*}{ Succinic acid } & \multirow{3}{*}{15} & Control & $3.77 \pm 0.08^{b}$ & $2.03 \pm 0.18^{c}$ & $\mathrm{ND}$ & $15.97 \pm 0.60^{\mathrm{a}}$ & $\mathrm{ND}$ \\
\hline & & Y204 & $5.02 \pm 0.21^{b}$ & $\mathrm{ND}$ & $17.69 \pm 1.10^{\mathrm{a}}$ & $\mathrm{ND}$ & $\mathrm{ND}$ \\
\hline & & Y283 & $\mathrm{ND}$ & $46.83 \pm 0.79^{\mathrm{a}}$ & $\mathrm{ND}$ & $3.83 \pm 0.08^{c}$ & $11.26 \pm 0.81^{b}$ \\
\hline & & Control & $9.69 \pm 0.52^{b}$ & $21.03 \pm 0.31^{a}$ & $\mathrm{ND}$ & $\mathrm{ND}$ & $\mathrm{ND}$ \\
\hline & 20 & Y204 & $6.37 \pm 0.03^{b}$ & $11.35 \pm 0.89^{\mathrm{a}}$ & $\mathrm{ND}$ & $\mathrm{ND}$ & $\mathrm{ND}$ \\
\hline & & Y283 & $\mathrm{ND}$ & $\mathrm{ND}$ & $12.35 \pm 0.93^{\mathrm{a}}$ & $\mathrm{ND}$ & $\mathrm{ND}$ \\
\hline & & Control & $9.24 \pm 0.10^{b}$ & $20.09 \pm 0.93^{\mathrm{a}}$ & $\mathrm{ND}$ & $\mathrm{ND}$ & $\mathrm{ND}$ \\
\hline & 25 & Y204 & $3.94 \pm 0.05^{\mathrm{b}}$ & $6.64 \pm 0.28^{\mathrm{a}}$ & $1.35 \pm 0.15^{\mathrm{c}}$ & $\mathrm{ND}$ & $\mathrm{ND}$ \\
\hline & & Y283 & $\mathrm{ND}$ & $14.00 \pm 0.23^{\mathrm{a}}$ & $\mathrm{ND}$ & $\mathrm{ND}$ & $\mathrm{ND}$ \\
\hline
\end{tabular}


(Table 2. Continued)

\begin{tabular}{|c|c|c|c|c|c|c|c|}
\hline \multirow{2}{*}{ Organic acid } & \multirow{2}{*}{$\begin{array}{l}\text { F.T } \\
\left({ }^{1)}\right. \\
\left({ }^{\circ} \mathrm{C}\right)\end{array}$} & \multirow{2}{*}{ Starters ${ }^{2)}$} & \multicolumn{5}{|c|}{ Fermentation period (day, mg/100 mL) } \\
\hline & & & 0 & 2 & 4 & 6 & 8 \\
\hline \multirow{9}{*}{ Fumaric acid } & \multirow{3}{*}{15} & Control & $\mathrm{ND}^{4)}$ & $5.15 \pm 0.23^{33)}$ & $\mathrm{ND}$ & $\mathrm{ND}$ & $\mathrm{ND}$ \\
\hline & & Y204 & ND & $1.80 \pm 0.03^{\mathrm{b}}$ & $3.20 \pm 0.05^{\mathrm{a}}$ & $\mathrm{ND}$ & $\mathrm{ND}$ \\
\hline & & Y283 & $2.06 \pm 0.08^{\mathrm{c}}$ & $18.92 \pm 1.12^{\mathrm{a}}$ & $\mathrm{ND}$ & $13.63 \pm 0.39^{\mathrm{b}}$ & $1.93 \pm 0.06^{\mathrm{c}}$ \\
\hline & \multirow{3}{*}{20} & Control & ND & $\mathrm{ND}$ & $\mathrm{ND}$ & $\mathrm{ND}$ & $\mathrm{ND}$ \\
\hline & & Y204 & ND & $\mathrm{ND}$ & $\mathrm{ND}$ & $\mathrm{ND}$ & $\mathrm{ND}$ \\
\hline & & Y283 & ND & $\mathrm{ND}$ & $\mathrm{ND}$ & $\mathrm{ND}$ & $\mathrm{ND}$ \\
\hline & \multirow{3}{*}{25} & Control & ND & $\mathrm{ND}$ & $\mathrm{ND}$ & $\mathrm{ND}$ & $\mathrm{ND}$ \\
\hline & & Y204 & $1.84 \pm 0.08^{\mathrm{a}}$ & $\mathrm{ND}$ & $\mathrm{ND}$ & $\mathrm{ND}$ & $\mathrm{ND}$ \\
\hline & & Y283 & $1.89 \pm 0.18^{\mathrm{a}}$ & $\mathrm{ND}$ & $\mathrm{ND}$ & $\mathrm{ND}$ & $\mathrm{ND}$ \\
\hline \multirow{9}{*}{ Propionic acid } & \multirow{3}{*}{15} & Control & $\mathrm{ND}$ & $1.40 \pm 0.01^{\mathrm{c}}$ & $8.16 \pm 0.07^{\mathrm{a}}$ & $2.00 \pm 0.23^{b}$ & $\mathrm{ND}$ \\
\hline & & Y204 & $1.63 \pm 0.09^{b}$ & $1.63 \pm 0.04^{b}$ & $4.35 \pm 0.13^{\mathrm{a}}$ & $\mathrm{ND}$ & $\mathrm{ND}$ \\
\hline & & Y283 & ND & $58.46 \pm 0.87^{\mathrm{a}}$ & $12.48 \pm 0.53^{b}$ & $11.50 \pm 0.52^{\mathrm{c}}$ & $4.36 \pm 0.03^{\mathrm{d}}$ \\
\hline & \multirow{3}{*}{20} & Control & $\mathrm{ND}$ & $\mathrm{ND}$ & $\mathrm{ND}$ & $\mathrm{ND}$ & $\mathrm{ND}$ \\
\hline & & Y204 & $1.21 \pm 0.11^{\mathrm{a}}$ & $\mathrm{ND}$ & $\mathrm{ND}$ & $\mathrm{ND}$ & $\mathrm{ND}$ \\
\hline & & Y283 & $1.30 \pm 0.07^{\mathrm{b}}$ & $11.98 \pm 0.59^{\mathrm{a}}$ & $\mathrm{ND}$ & $\mathrm{ND}$ & $\mathrm{ND}$ \\
\hline & \multirow{3}{*}{25} & Control & $\mathrm{ND}$ & $\mathrm{ND}$ & $\mathrm{ND}$ & $\mathrm{ND}$ & $\mathrm{ND}$ \\
\hline & & Y204 & $\mathrm{ND}$ & $\mathrm{ND}$ & $\mathrm{ND}$ & $\mathrm{ND}$ & $\mathrm{ND}$ \\
\hline & & Y283 & $1.41 \pm 0.07^{b}$ & $10.75 \pm 0.74^{\mathrm{a}}$ & $\mathrm{ND}$ & $\mathrm{ND}$ & $\mathrm{ND}$ \\
\hline
\end{tabular}

${ }^{12}$ F.T, fermentation temperature.

${ }^{2)}$ Control, Saccharomyces cerevisiae Fermivin; Y204, S. cerevisiae Y204 (KACC 93237P); Y283, S. cerevisiae Y283 (KACC 93238P).

${ }^{3)}$ Means with different letters in the same row are significantly different $(\mathrm{p}<0.05)$ by Ducan's multiple range test.

${ }^{4} \mathrm{ND}$, Not detected.

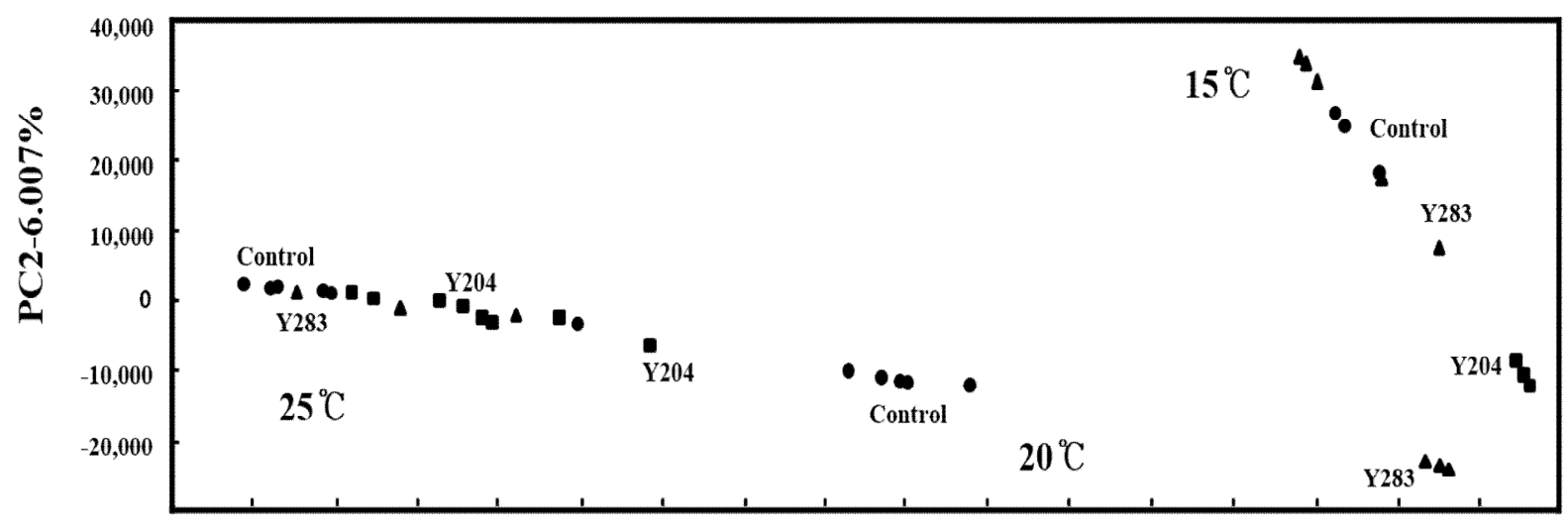

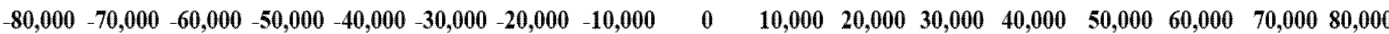

PC1-92.705\%

Fig. 3. Principal component analysis of changes in the pattern of multiple volatile components for glutinous rice-Makgeolli according to different fermented starters during fermentation temperature by electronic nose. A different colors was displayed by according to different fermentation temperatures.

- S. cerevisiae Fermivin; $\mathbf{\square}$ S. cerevisiae Y204; $\boldsymbol{\Delta}$, S. cerevisiae Y283.

가 높을수록, 또는 발효기간이 길어질수록 이들 유기산이 나타나지 않았다. 발효 종균인 Y283 효모로 빚은 찹쌀막걸
리는 각각의 유기산 농도가 발효 2 일째, 저온인 $15^{\circ} \mathrm{C}$ 에서 향미에 좋은 영향을 미치는 citric $\operatorname{acid}(540.98 \mathrm{mg} / 100 \mathrm{~mL})$ 와 
부드러운 신맛을 내는 malic $\operatorname{acid}(105.92 \mathrm{mg} / 100 \mathrm{~mL})$ 가 가 장 높게 나타났다. 이들 유기산 함량은 Y204 효모 종균에서 는 발효 2일 차 두 번째로 높게 나타났고, 대조구인 수입산 효모인 Fermivin에서는 발효 4일 차 세 번째 함량을 나타내 었다. 앞에서 언급한 알코올 함량과 비교한 결과, $S$. cerevisiae Y283 종균은 발효기간이 2일 단축됨으로써 $S$. cerevisiae Y204와 수입산 효모(S. cerevisiae Fermivin)보다 막걸리를 빚을 때, 부대비용 절감 등을 고려하면 높은 경제 성이 높은 것으로 보였다.

\section{찹쌀막걸리의 향기패턴 분석}

효모 종균별 온도에 따른 찹쌀막걸리의 다중 향기패턴 분석을 Fig. 3 에 나타내었다. 향기패턴을 구분하는 제 1 주성 분 값의 기여율(proportion)은 $92.71 \%$ 이었으며, 제 2 주성분 값의 기여율은 $6.01 \%$ 로 각각의 발효온도별 제조된 찹쌀막 걸리의 향기패턴의 차이를 확인하였다. 발효 온도가 증가 함에 따라서 향기패턴이 제 1 주성분의 값의 $-80,000$ 과 0 사 이에 분포하였다. 저온인 $15^{\circ} \mathrm{C}$ 에서 발효한 3 종류의 효모 종균별로 빚은 찹쌀막걸리는 발효 속도가 늦어 $20^{\circ} \mathrm{C}$ 와 $25^{\circ} \mathrm{C}$ 와의 향기패턴과는 거리가 많이 떨어져 있기에 서로 다른 향이라고 판단할 수가 있다. $20^{\circ} \mathrm{C}$ 로 발효한 3 종류 찹쌀막걸 리(Fermivin, Y204, Y283)는 다른 온도 $\left(15^{\circ} \mathrm{C}, 25^{\circ} \mathrm{C}\right)$ 보다 집 약적이지가 않고 범위가 넓음을 알 수가 있었다. 따라서 $15^{\circ} \mathrm{C}$ 와 $25^{\circ} \mathrm{C}$ 에서 발효한 찹쌀막걸리보다 향기성분의 패턴 다양성을 알 수 있었으며, $15,25^{\circ} \mathrm{C}$ 에서 발효를 하였을 때, $20^{\circ} \mathrm{C}$ 보다 더 일정한 향기패턴을 갖는 찹쌀막걸리를 얻을 수 있었던 것은 서서히 발효되는 낮은 온도의 안정성과 빠르게 발효되는 높은 온도의 안정성 때문인 것 같다. $25^{\circ} \mathrm{C}$ 로 발효한 3 종류의 찹쌀막걸리는 $15^{\circ} \mathrm{C}$ 와는 다른 향이라고 판단을 할수가 있었으며, 저온에서 발효한 찹쌀막걸리보다 $\mathrm{y}$ 축에 가까이 집약된 패턴을 볼 수가 있다.

\section{요 약}

Aspergillus luchuensis 74-5로 제조한 쌀누룩에 서로 다른 3종류의 효모(Fermivin, Y204, Y283) 종균을 이용하여 빚은 찹쌀막걸리의 품질 특성을 규명하기 위해 이화학적 특성과 휘발성 향기 패턴을 비교하였다. 서로 다른 발효조건에 따 른 찹쌀막걸리의 $\mathrm{pH}$, 총산, 아미노산도, 당과 알코올 함량, 유기산 및 향기 패턴을 분석하였다. 전반적으로 $\mathrm{pH}$ 는 3.11-3.82의 범위로 매우 낮은 수준을 나타냈다. 발효 종균 효모 Y283으로 빚은 찹쌀막걸리의 산도는 발효 $15^{\circ} \mathrm{C}$ 에서 $0.96 \%$ 로, $20^{\circ} \mathrm{C}$ 에서는 $1.02-1.07 \%$ 로 증가, $25^{\circ} \mathrm{C}$ 에서는 $1.11 \%$ 로 최고의 증가를 보이면서 대조구인 Fermivin와 $\mathrm{Y} 204$ 로 빚은 찹쌀막걸리보다 발효능이 높게 나타났다. 또 한 $\mathrm{Y} 283$ 찹쌀막걸리의 알코올 생성은 $15^{\circ} \mathrm{C}$ 에서 $16 \%$ 로, $20^{\circ} \mathrm{C}$ 에서는 $17.8 \%$ 로 높으며 대조구로 사용한 Fermivin과 $\mathrm{Y} 204$ 효모로 빚은 찹쌀막걸리에 비해 유의적인 차이를 보 였다(p<0.05). 한편, 유기산 변화에서도 효모 $\mathrm{Y} 283$ 찹쌀막 걸리의 citric $\operatorname{acid}(540.98 \mathrm{mg} / 100 \mathrm{~mL})$ 와 malic $\operatorname{acid}(105.92$ $\mathrm{mg} / 100 \mathrm{~mL}$ )가 $15^{\circ}$ 에서 높은 함량을 나타내었다. 전자코에 의한 제 1 주성분 값의 $92.71 \%$ 기여율로 발효 온도별 제조된 막걸리의 향기성분 패턴 또한 다양한 것을 알 수 있었다. 결국, 발효온도에 따른 효모 종균별 제조된 찹쌀막걸리의 이화학적 특성과 향기 패턴에 영향을 주었다. 특히, 효모 Y283 종균으로 빚은 찹쌀막걸리는 막걸리의 품질을 향상 시키는데 도움을 줄 것으로 기대된다.

\section{감사의 글}

이 논문은 농촌진흥청 농업과학기술개발사업(과제번호: PJ01248302)의 지원에 의해 이루어진 것이며, 연구비 지원 에 감사드립니다.

\section{References}

1. Kim DR, Seo BM, Noh MH, Kim YW (2012) Comparison of temperature effects on brewing of Makgeolli using uncooked germinated black rice. Korean Soc Biotechnol Bioeng J, 27, 251-256

2. Park CS, Lee TS (2002) Quality characteristics of Takju prepared by wheat flour Nuruks. Korean J Food Sci Technol, 34, 296-302

3. Kim BH, Eun JB (2012) Physicochemical and sensory characteristics of Makgeolli with pomegranate (Punica granatum L.) juice concentrate added. Korean J Food Sci Technol, 44, 417-421

4. Kim HR, Jo SJ, Lee SJ, Ahn BH (2008) Physiochemical and sensory characterization of a Korean traditional rice wine prepared from different ingredients. Korean J Food Sci Technol, 40, 551-557

5. Prathepha P, Daipolmak V, Samappito A, Baimal V (2005) An assessment of alkali degradation, waxy protein, and their relation to amylose content in Thai rice cultivars. J Sci Soc Thailand, 31, 69-75

6. Shin HS, Rhee JY (1986) Comparative studies on the lipid content and neutral lipid composition in nonglutinous and glutinous rice. Korean J Food Sci Technol, 18, 137-142

7. Eun JB, Jin TY, Wang MH (2007) The effect of waxy glutinous rice degree of milling on the quality of 
Jinyangju, a Korean traditional rice wine. Korean J Food Sci Technol, 39, 546-551

8. Jin TY, Chung HJ, Eun JB (2006) The effect of fermentation temperature on the quality of Jinyangju, a Korean traditional rice wine. Korean J Food Sci Technol, 38, 414-418

9. Park YM, Kim SJ, Hwang IS, Cho KH, Jung ST (2005) Physicochemical and sensory properties of Jinyangju prepared with glutinous rice and nonglutinous rice. Korean J Food culture, 20, 346-351

10. Baek CH, Baek SY, Mun JY, Choi HS, Kang JE, Jung ST, Yeo SH (2016) Quality characteristics and preparing of solid starter using fungal strains for Takju. Korean J Food Presev, 23, 797-803

11. Yu JC (2013) Research into brewing characteristics and liquor quality stability associated with type of yeasts. MS Thesis, Hankyong National University, Korea, p 1-5

12. Kim HR, Kwon YH, Jo SJ, Kim JH, Ahn BH (2009) Characterization and volatile flavor components in glutinous rice wines prepared with different yeasts of Nuruks. Korean J Food Sci Technol, 41, 296-301

13. Jeon HJ, Yu JC, Kim GW, Kong HS (2014) Quality characteristics of Takju by yeast strain type. Korean J Food Nutr, 27, 971-978

14. Roh HI, Chang EH, Joeng ST, Jahng KY (2008) Characteristics of fermentation and wine quality. Korean J Food Preserv, 15, 317-324

15. Lee CH, Tae WT, Kim GM, Lee HD (1991) Studies on the pasteurization conditions of Takju. Korean J Food Sci Technol, 23, 44-51

16. Joung EJ, Paek NS, Kim YM (2004) Studies on Korean Takju using the by-product of rice milling. Korean J Food Nutr, 17, 199-205

17. Kim IH, Park WS, Koo YJ (1996) Comparison of fermentation characteristics of Korean traditional alcoholic beverage with different input step and treatment of rice and Nuruk Korean J Diet Cult, 11, 339-348

18. Park CS, Lee TS (2002) Quality characteristics of Takju prepared by wheat flour Nuruks. Korean J Food Sci Technol, 34, 296-302

19. Jang DB, Lee HJ, Pyo SE, Roh SW, Rhee JK, Lee HS (2014) Fermentation and quality evaluation of Makgeolli, Korean rice wine supplemented with alcohol-tolerant Pediococcus acidilactici K3. Korean J Microbiol Biotechnol, 42, 367-376

20. Rozes N, Larue F, Ribereau-Gayon P (1988) Effect of a variation of grape must temperature on the fermentative ability and the neutral lipid content of Saccharomyces cerevisiae. Biotechnol Lett, 10, 821-824

21. Jin TY, Chung HJ, Eun JB (2006) The effect of fermentation temperature on the quality of Jinyangju, a Korean traditional rice wine. Korean J Food Sci Technol, 38, 414-418

22. Kang SM, Kim SJ, Ko KH, Nam SH (2016) Formation of biogenic amines and bioactivities of Makgeolli under different fermentation conditions. Korean J Food Presev, 23, 402-412

23. Lee YJ, Yi HC, Hwang KT, Kim DH, Kim HJ, Jung CM, Choi YH (2012) The qualities of Makgeolli (Korean rice wine) made with different rice cultivars, milling degree of rice, and Nuruks. J Korean Soc Food Sci Nutr, $41,1785-1791$

24. Kim CJ (1968) Microbiological and enzymological studies on Takju brewing. J Korean Soc Appl Biol Chem, $10,69-100$

25. So MH, Lee YS, Noh WS (1999) Changes in microorganisms and main components during Takju brewing by a modified Nuruk Korean J Food Nutr, 12, 226-232

26. Yang HS, Eun JB (2011) Fermentation and sensory characteristics of Korean traditional fermented liquor (Makgeolli) added with citron (Citrus junos SIEB ex TANAKA) juice. Korean J Food Sci Technol, 43, 438-445

27. Jang HW, Ryu YW (1992) Study on the factors affecting the ethanol tolerance of yeast strains by fermentation temperature. Korean J Biotech Bioeng, 7, 33-37

28. Kim HJ, Ryu YW (1989) The conditions affecting ethanol tolerance of yeast strains in alcohol fermentation-Study on the fermentation temperature and substrate type. Korean J Biotechnol Bioeng, 4, 167-171

29. Kim HR, Kwon YH, Jo SJ, Kim JH, Ahn BH (2009) Characterization and volatile flavor components in glutinous rice wines prepared with different yeasts of Nuruks. Korean J Food Sci Technol, 41, 296-301

30. Im CY (2012) Quality characteristics of persimmon Makgeolli on the processing forms of added persimmon and containing persimmon. MS Thesis, Kyungpook National University, Korea, p 2-6

31. Lee TJ, Hwang DY, Lee CY, Son HJ (2009) Changes in yeast cell number, total acid and organic acid during production and distribution processes of Makgeolli, traditional alcohol of Korea. Korean J Microbiol, 45, 391-396 
32. Woo SM, Shin JS, Seong JH, Yeo SH, Choi JH, Kim TY, Jeong YJ (2010) Quality characteristics of brown rice Takju by different Nuruks. J Korean Soc Food Sci Nutr, 39, 301-307

33. Choi SH, Kim OK, Lee MW (1992) A study on the gas chromatographic analysis of alcohols and organic acids during Takju fermentation. Korean J Food Sci Technol, 24, 272-278

34. Kim CW, Kang JE, Jeong ST, Choi HS (2017) Physicochemical properties of non-sterilized Makgeolli prepared using different fermentation starters and storage conditions. J East Asian Soc Diet Life, 27, 629-634 